de M. Steenstrup. Si vous consultez le Record of Zoological Literature pour 1869 (vol. vi.), vous y trouverez, p. I39:-

"Selache maxima.-A detailed description and figure of an example from the coast of Portugal is given by $M$. Capello under the name of Cetorkinus blainvillii, Four. Ac. Sc. Lisbon, No. vii., p. 233."

Je vous envoie par la poste le No. vii. du Four. des Sc. de Lisbonne. J. N. Barbosa Bocage

\section{Gold in Carboniferous Conglomerate}

MANY of your readers are aware that the fact of the occurrence of gold in Lower Carboniferous conglomerate as in New South Wales is not at all new. The Gay's River Gold Field of Nova Scotia, where the gold occurs in Lower Carboniferous conglomerate resting on the edges of Cambrian slates having small veins of auriferous quartz, was first pointed out by Prof. Hartt and elaborated by myself in a paper communicated to the Nova Scotian Institute of Natural Science in I866. In Dawson's "Accadian Geology," of 1868 , the same fact is referred to ; also in Seluria, Prof. R. Jones received specimens of the conglomerate from me in Paris, 1867 , to satisfy Sir R. J. Murchison of the fact. In the collection of ores and concrete minerals sent by II. S. Poole, Esq., Government Inspector of Mines to the Centennial Exhibition, in my charge, was a very instructive specimen of slate with a little of the conglomerate attached, having a beautiful display of gold. This was much admired. The conglomerate of Gay's River is overlaid by limestone with Lower Carboniferous fauna and gypsums. The conglomerate is worked still with good results.

Provincial Museum, Halifax, Nova Scotia

\section{Japanese Mirrors}

A sHORT time ago a friend showed me a curious effect, which I had previously heard of, but had never seen. The ladies of Japan use, in making their toilet, a small round mirror about $\frac{1}{12}$ to $\frac{1}{5}$ inch in thickness, made of a lind of specultum metal, brightly poltshed and coated with mercury. At the back there are usually various devices, Japanese or Chinese written characters, badges, $\& \approx$, standing in strong relief, and brightly polished like the front surface. Now if the direct rays of the sun are allowed to fall upon the front of the mirror and are then reflected on to a screen, in a great many cases, though not in all, the figures at the back will appear to shine through the substance of the mirror as bright lines upon a moderately bright ground.

I have since tried several mirrors as sold in the shops, and in most cases the appearance described has been observed with more or less distinctness.

I have been unable to find a satisfactory explanation of this fact, but on considering the mode of manufacture $I$ was led to suppose that the pressure to which the mirror was subjected during polishing, and which is greatest on the parts in relief, was concerned in the production of the figures. On putting this to the test by rubbing the back of the mirror with a blunt pointed instrument, and permitting the rays of the sun to be reflected from the front surface, a bright line appeared in the image corresponding to the position ot the part rubbed. This experiment is quite easy to repeat, a scratch with a knife or with any other hard body is sufficient. It would seem as if the pressure upon the back during polishing caused some change in the reflecting surface corresponding to the raised parts whereby the amount of light reflected was greater ; or supposing that of the light which falls upon the surface, a part is absorbed and the rest reflected, those parts corresponding to the raised portions on the back are altered by the pressure in such a way that less is absorbed, and therefore a bright image appears. This, of course, is not an explanation of the phenomenou, but $I$ put it forward as perhaps indicating the direction in which a true explanation may be looked for.

The following account of the manufacture of the Japanese mirrors is taken from a paper by Dr. Geerts, read before the Asiatic Society of Japan, and appearing in their Transactions for I875-76, p. 39 :-

"For preparing the mould, which consists of two halves, put together with their concave surfaces, the workman first powders a kind of rough plastic clay, and mixes this with levigated powder of a blackish "tuff-stone" and a little charcoal powder and water, till the paste is plastic and suitable for being moulded. It is then roughly formed by the aid of a wooden frame into square or round cakes; the surface of the latter is covered with a levi- gated half-liquid mixture of powiered "chamotte" (old crucibles which have served for melting bronze or copper) and water Thus well prepared, the blackish paste in the frame receives the concave designs by the aid of woodcuts, cut in relief. The two halves of the mould are put together in the frame and dried. Several of these flat moulds are then placed in a melting box made of clay and "chamotte." This box has on the top an opening, into which the liquid bronze is poured, after it has been melted in small fire-proof clay crucibles. The liquid metal naturally fills all openings inside the box, and consequently also the cavities of the moulds. For mirrors of first quality the fol lowing metal mixture is used in one of the largest mirror foundries in Kiôto :-

$\begin{array}{lcccccc}\text { Lead } & \ldots & \ldots & \ldots & \ldots & \ldots & 5 \text { parts. } \\ \text { Tin } & \ldots & \ldots & \ldots & \ldots & \ldots & 15 \\ \text { Copper } & \ldots & \ldots & \ldots & \ldots & \ldots & \frac{80}{100}\end{array}$

For mirrors of inferior quality is taken-

$\begin{array}{lllllll}\text { Lead } & \ldots & \ldots & \ldots & \ldots & \ldots & \text { Io parts. } \\ \text { Natural sulphide of lead and antimony } & \text { ro } \\ \text { Copper } & \ldots & \ldots & \ldots & \ldots & \ldots & \text { 80 }\end{array}$

"After being cooled the melling-box and moulds are crushed and the mirrors taken away. 'These are then cut, scoured, and filed until the mirror is roughly finished. They are then first polished with a polishing powcer called $10-220 \cdot k i$, which consists of the levigated powder of a soft kind of whetstone (to-ishi) found in Yamato and many cther places. Secondly, the mirrors are polished with a piece of charcoal and water, the charcoal of the wood, ho-no-ki (Magnolia hypoleuca) being preferred as the best for this purpose. When the surface of the mirror is well polished it is covered with a layer of mercury amalgam, consisting of quicksilver, tin, and a little lead. The amalgam is rubbed vigorously with a piece of soft leather, which manipulation must be continued for a long time until the excess of mercury is expelled and the mirror lias got a fiie, bright, reflecting surface."

University of Tokio, Japın

\section{THE DECENNIAL PERTOD OF MAGNETIC VARIATIONS, AND OF SUN-SPOT FRE- OUENCY}

A CENTURY and half ago Graham discovered that A the north end of a magnetic needle moved from morning till afternoon towards the west, returning thereafter to its most easterly position in the morning again. Van Swinden, who, half a century later, studied this phenomenon during several years, occupied himself greatly with the deviations from the diurnal law. One of these, the occurrence of the greatest westerly position before noon or after 4 P.M., he found to happen most frequently in 1776 , the number of times increasing from I 772 , and diminishing from the year of maximuin till 1780. He then asked the question whether there was not a period of eight years. Van Swinden's results were greatly affected by imperfections of his instrument, and we can only consider that the excess of irregular days in 1776 was probably chiefly due to real causes.

Though several series of magnetic observations were made during the eighteenth century, and two series early in this (those of Beaufoy and Arago), yet, as far as I can discover, Kaemtz seems (in 1836 ) to have been the first to remark that the mean value of the diurnal oscillation of the magnetic needle was not constant, but varied from year to year: this conclusion he founded on Cassini's observations, which gave the mean oscillation $9.7 \mathrm{I}$ in 1784 , and $15^{\prime} 10$ in 1787 . The illustrious Gauss drew more distinct attention to the fact, for, in studying the observations made at Göttingen in the years 1834 to I 837 , he pointed out that the mean diurnal oscillation for each month in the second year was greater than that for the corresponding month of the first year; and that a similar increase was to be found in the third year compared with 